НАУКОВИЙ ВІСНИК

(10x)

Sientific messenger or Lviv National University of

Medicine and Botechnologies

(2)

TIIIII

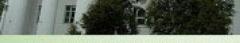

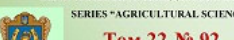

2020

Науковий вісник Яьвівського національного університету ветеринарної медицини та біотехнологій імені С.3. Гжицького. Серія: Сільськогосподарські науки

Scientific Messenger of Lviv National University of Veterinary Medicine and Biotechnologies. Series: Agricultural sciences

UDC 637.354 .8

\title{
Growth intensity and antibacterial properties of Enterococcus faecium and Enterococcus durans strains isolated from traditional Carpathian brynza
}

\author{
I. I. Kushnir ${ }^{1}$, O. Y. Tsisaryk ${ }^{1}$, I. M. Slyvka ${ }^{1}$, L. Y. Musiy ${ }^{1}$, I. M. Kushnir ${ }^{2}$, I. S. Semen ${ }^{2}$ \\ ${ }^{I}$ Stepan Gzhytskyi National University of Veterinary Medicine and Biotechnologies Lviv, Lviv, Ukraine \\ ${ }^{2}$ State Scientific-Research Control Institute of Veterenary Medicinal Products and Feed Additives, Lviv, Ukraine
}

\section{Article info}

Received 03.02.2020

Received in revised form 03.03 .2020

Accepted 04.03.2020

Stepan Gzhytskyi National University of Veterinary Medicine and Biotechnologies Lviv, Pekarska Str., 50, Lviv, 79010, Ukraine.

State Scientific-Research Control Institute of Veterenary Medicinal Products and Feed Additives,

Donetsk Str., 11, Lviv,

79010, Ukraine.

Тел.: +38-098-29-01-694; +38-067-600-11-04; $+38-097-986-15-44$ $+38-098-132-31-63$ +38-096-36-73-137.

E-mail: irynakushn@gmail.com; tsisaryk_o@yaoo.com; slyvka.88@ukr.net; musiyluba@ukr.net; igorku70@gmail.com
Kushnir, I. I., Tsisaryk, O. Y., Slyvka, I. M., Musiy, L. Y., Kushnir, I. M., \& Semen, I. S. (2020). Growth intensity and antibacterial properties of Enterococcus faecium and Enterococcus durans strains isolated from traditional Carpathian brynza. Scientific Messenger of Lviv National University of Veterinary Medicine and Biotechnologies. Series: Agricultural sciences, 22(92), 42 49. doi: $10.32718 /$ nvlvet-a9208

The article presents the results of the study the ability of four not studied strains of enterococci (E. durans, SB6, E. faecium SB12, E. durans SB18, E. durans SB20), which were isolated from the Carpathian brynza, to reduce the acidity of medium of cultivation, the rate of biomass accumulation and the ability to exhibit antagonistic properties to the opportunistic microflora. Lactic acid and minor compounds are producing in a result of lactose fermentation, which form the specific taste and aroma properties of the product. The activity of acid formation has crucial because it directly connected with the coagulation of proteins and the prevention of the growing of extraneous microflora. Therefore, the rate of acidity increasing of the medium is one of the most important characteristics in selection of strains of lactic acid bacteria for the manufacture of dairy products. High growth rate, resistance to the contamination of extraneous microflora and preservation of their properties in the finished product are the technological properties of the strains. The inhibition of the growth of pathogenic cultures of microorganisms is the main probiotic functions of beneficial bacteria namely antagonistic activity. It was found, that the strain E. durans SB20 manifested the highest ability to increase the acidity of the medium under the cultivation for 24 hours at $37^{\circ} \mathrm{C}$ as it reduced the $\mathrm{pH}$ on $30.3 \%$, and the strain E. durans SB18 increased the acidity on $29.9 \%$. Under 48 hours strains E. durans $S B 20$ and SB18 increased the acidity on 31.1 and $30.5 \%(P<0.001)$ respectively compared with the control. The growth rate of stains E. durans SB20 and E. durans SB18 were in 18,0 and 17,6 times higher than in control under the cultivation for 24 hours at $37^{\circ} \mathrm{C}$, the optical density were in 18.3 and 18.2 times higher respectively than in the control sample under the cultivation for 48 hours at the same temperature. Furthermore, strains of enterococci showed antagonistic properties against conditionally pathogenic cultures of microorganisms on 24 and 48 hour of cultivation. In addition, it was found that with an increasing temperature of the antagonistic activity of the strains cultivation increased. Obviously, it was connected that more biologically active substances and microbial secondary metabolites are formed under the longer cultivation and higher temperatures. In particular on 48 hours at $37{ }^{\circ} \mathrm{C}$ almost of all the tested strains showed moderate antagonistic activity against E. coli, S. enteritidis, E. aerogenes, P. mirabilis and $P$. aeruginosa. However, all four strains didn` thave antagonistic activity against the test-strain S. aureus.

Key words: Enterococcus durans, E. faecium, acidity, growth rate, antagonistic activity, Carpathian cheese brynza, probiotics.

\section{Інтенсивність росту та антибактеріальні властивості штамів Enterococcus faecium ma Enterococcus durans, виділених із традиційної карпатської бринзи}

\author{
I. І. Кушнір ${ }^{1}$, О. Й. Цісарик ${ }^{1}$, І. М. Сливка ${ }^{1}$, Л. Я. Мусій${ }^{1}$, I. М. Кушнір ${ }^{2}$, I. С. Семен ${ }^{2}$
}


${ }^{1}$ Львівський національний університет ветеринарної медицини та біотехнологій імені С. 3. Гжиџького, м. Львів, Україна

${ }^{2}$ Державний науково-дослідний контрольний інститут ветеринарних препаратів та кормових добавок, м. Львів, Україна

У статті наведено результати досліджень із вивчення здатності чотирьох невивчених итамів ентерококів (E. dигапs, SB6, E. faecium SB12, E. durans SB18, E. durans SB20), виділених із карпатської бринзи, знижувати кислотність середовища культивування, швидкість накопичення біомаси та здатність проявляти антагоністичні властивості до умовно-патогенної мікрофлори. У результаті зброджування лактози утворюється молочна кислота та мінорні сполуки, які формують специфічні смакові та ароматичні властивості продукту. Активність кислотоутворення має вирішальне значення, оскільки із цим безпосередньо пов 'язана коагуляція білків, а також попередження розвитку сторонньої мікрофлори. Тому швидкість зниження кислотності середовища є однією із найважливіших характеристик при відборі штамів молочнокислих бактерій для виготовлення кисломолочних продуктів. Технологічність штамів полягає у їх високій швидкості росту, стійкості до забруднення сторонньою мікрофлорою та збереженні свойх властивостей у готовому препараті. Основними пробіотичними функціями корисних бактерій є пригнічення росту патогенних культур мікроорганізмів, тобто антагоністична активність. У результаті проведених досліджень, встановлено, що на 24 год культивування за температури $37{ }^{\circ} \mathrm{C}$ найвищу здатність підвищувати кислотність середовища проявляв штам Е. дигапs SB20, оскільки був здатним знизити рН середовища на 30,3 \%, а E. durans SB18 підвищував кислотність на 29,9 \%, а на 48 год штами E. durans SB20 та SB18 підвищували кислотність на 31,1 та 30,5\% (P < 0,001) відповідно порівняно з контролем. Було встановлено, щео на 24 год культивування ентерококів за температури $37{ }^{\circ} \mathrm{C}$ інтенсивність росту штамів E. durans SB20 та E. durans SB18 була в 18,0 та 17,6 разів вищзю, ніж у контролі, на 48 год культивування за ијєї самої температури оптична густина була відповідно у 18,3 та 18,2 рази вищою у порівнянні із контрольним зразком. Крім цьього, досліджувані штами ентерококів проявляли антагоністичні властивості щодо умовно-патогенних культур мікроорганізмів на 24 та 48 год культивування. Було встановлено, щзо із збільшенням температури культивування зростала антагоністична активність штамів. Очевидно, це пов'язано із тим, щзо при тривалішому культивуванні і вищих температурних режимах утворюється більше біологічно активних речовин та вторинних продуктів життєдіяльності мікроорганізмів. Зокрема, на 48 год за температури $37^{\circ}$ С майже всі досліджувані штами проявляли помірну антагоністичну активність щьоо E. coli, S. enteritidis, E. aerogenes, P. mirabilis ma P. aeruginosa. Проте, всі чотири итами взагалі не володіли антагоністичною активністю щяодо тест-штаму $S$. аигеиs.

Ключові слова: Enterococcus durans, E. faесіит, кислотність, ивидкість росту, антагоністична активність, карпатська бринза, пробіотики.

\section{Вступ}

Проблема захворювань шлунково-кишкового тракту різної етіології є надзвичайно важливим питанням сучасної медицини. Згідно з даними наукової літератури у 75-90 \% населення України виявляють дисбактеріози (Tihomirova, 2002). Дисбактеріоз, включає зміни видового складу і метаболічної активності кишкової мікрофлори, внаслідок чого ускладнює перебіг багатьох захворювань за рахунок порушення функціонування імунної системи організму (Jushhuk \& Brodov, 2001). У результаті зниження кількості молочнокислих мікроорганізмів порушуються процеси травлення, погіршується всмоктування речовин, синтез вітамінів, знижується стійкість кишечника до заселення його умовно-патогенними та патогенними мікроорганізмами (Strel'nikov et al., 2006; Sornplang \& Piyadeatsoontorn, 2016).

Причиною зниження кількості корисної мікрофлори $є$ ряд чинників, серед яких головними $є$ неконтрольоване використання антибіотиків та неякісних біологічних добавок, надмірне використання харчових добавок, консервантів, барвників тощо (Gordijenko et al., 2009; Jankovskij et al., 2010).

Основним засобом профілактики і лікування захворювань шлунково-кишкового тракту, спричинених дисбактеріозом, є пробіотичні препарати, використання яких дозволяє покращити стан мікрофлори кишечника макроорганізму, що сприяє покращанню загального стану здоров'я (Hyzhnjak, 2017).

Пробіотики - це живі клітини мікроорганізмів, адаптовані до певних умов існування. Симбіотична мікрофлора людей, які проживають в регіонах з різними кліматичними умовами, раціонами харчування не $\epsilon$ абсолютно однаковою. Тому слід приймати до уваги тісну взаємодію між мікрофлорою людини та екзогенним мікробним світом (Shenderov, 2001; Shyrobokov et al., 2008). Тобто, найефективнішими $\epsilon$ пробіотики, основу яких складають штами мікроорганізмів, що циркулюють у певній місцевості. Принциповою перевагою вітчизняних пробіотиків є адаптованість штамів мікроорганізмів до певної популяції населення. Тому, створення пробіотиків на основі українських біоваріантів фізіологічної мікрофлори $\epsilon$ актуальним та важливим завданням біотехнології (Jankovskyj et al., 2009).

3 іншого боку, при розробленні ефективних пробіотичних препаратів значна увага приділяється критеріям відбору пробіотичних культур. Основними пробіотичними функціями корисних бактерій в організмі людини є активне вибіркове пригнічення росту патогенних культур мікроорганізмів, тобто антагоністична активність. Крім того, пробіотичні культури повинні бути наділеними високою стійкістю до несприятливих умов середовища (стійкістю до жовчі, шлункового соку, протеолітичних ферментів, лізоциму, Натрію хлориду, високих значень рН тощо), що опосередковано вказує на здатність штамів виживати у шлунково- кишковому тракті (Duc et al., 2004; Ezendam et al., 2005; Yaneisy et al., 2016; Choi et al., 2018).

Важливою функцією пробіотичних штамів є технологічність, насамперед, висока швидкість росту, використання для своєї життєдіяльності дешевих субстратів, стійкість до забруднення сторонньою мікрофлорою, збереження в готовому препараті пробіотичних властивостей (Tuomola et al., 2001). Для забезпечення здоров'я людини до представників корисної мікрофлори ставляться вимоги щодо чіткої їх 
ідентифікації. Крім того, пробіотичні штами мають бути генетично стабільними та безпечними і не проявляти побічної дії на макроорганізм (Botyna, 2008).

За цих умов, важливу роль відіграє походження джерела пробіотика. Бажано, щоб продуцент був виділений із еконіші тієї території, де буде застосовуватись препарат (Ezendam et al., 2005; Dehtjarenko et al., 2005).

В останні роки увага вчених прикута до ентерококів, як потенційних пробіотичних препаратів. Дослідження показали, що ентерококи можуть використовуватися у складі заквашувальних препаратів, як захисні культури або пробіотики. Однак, дуже мало ентерококів було використано як пробіотики або кормові добавки через проблему пов'язану із можливим потенційним фактором їх вірулентності та наявності генів стійкості до антибіотиків (Braïek \& Smaoui, 2019).

На життєздатність ентерококів, значною мірою, впливає їх стійкість до $\mathrm{pH}$ середовища в якому вони перебувають (White, 2008). Як правило, ентерококи здатні витримувати рН в діапазоні від 4,0 до 9,6 одиниць в залежності від виду мікроорганізма (Giraffa, 2003). Зокрема, було встановлено, що досліджуваний штам E. faecium здатний давати максимальний ріст на живильному середовищі МРС у нейтральному або слабо-лужному середовищі, що коливається в межах 6,0-9,0 одиниці та продукувати у такому середовищі бактеріоцини. У кислому середовищі (pH 4,0 та 5,0 одиниць) ріст мікроорганізмів зменшувався, проте здатність продукувати бактеріоцини ще залишалася, тоді як при рН 3,0 одиниці росту мікроорганізмів не спостерігали (Franz et al., 1996).

Під час ферментації молока молочнокислими бактеріями відбувається синтез головної сполуки - молочної кислоти та низки мінорних сполук, які формують специфічні смакові та ароматичні властивості продукту. Продукування молочної кислоти є однією із найважливіших характеристик при відборі штамів для виготовлення ферментованих кисломолочних продуктів. Слід звернути увагу, що для виробництва сиру на початкових етапах підготовки вирішальне значення має швидкість зниження $\mathrm{pH}$ середовища, оскільки із цим безпосередньо пов'язана коагуляція білків, а також попередження розвитку сторонньої мікрофлори (Sarantinopoulos et al., 2001).

Тому метою нашої роботи було вивчити здатність ентерококів E. durans, SB6, E. faecium SB12, E. durans $\mathrm{SB} 18$, E. durans SB20, виділених із традиційної карпатської бринзи (Slyvka et al., 2018), підвищувати кислотність середовища культивування за різних температурних режимів та встановити їх антагоністичну активність щодо патогенних та умовнопатогенних мікроорганізмів.

\section{Матеріал і методи досліджень}

3 метою визначення здатності різних штамів $E$. $d u$ rans, SB6, E. faecium SB12, E. durans SB18, E. durans SB20 підвищувати кислотність середовища проводили їх культивування у рідкому МРС. 3 цією метою культури ентерококів культивували на твердому МРС за температури $37^{\circ} \mathrm{C}$ упродовж 18-20 год. Після чого стерильним ізотонічним розчином Натрію хлориду проводили змиви і готували завись мікроорганізмів на 0,5 одиниць за стандартом McFarlend. У колби із рідким живильним середовищем МРС вносили змиви культур із розрахунку $1,5 \times 10^{8} \mathrm{KУO} / \mathrm{cm}^{3}$. Досліджувані проби культивували за таких температурних режимів: $25,30,37^{\circ} \mathrm{C}$ упродовж 24 та 48 год. Визначення $\mathrm{pH}$ середовища проводили потенціометричного за допомогою $\mathrm{pH}$ метра Master LAB. Оптичну густину середовища культивування визначали за допомогою приладу КФК-3 при довжині хвилі 590 нм.

Для встановлення антагоністичної активності, виділені з бринзи ентерококи, засівали у рідке середовище MPC (Himedia, Індія) та культивували упродовж 24 та 48 год за температури $25,30,37^{\circ} \mathrm{C}$, після чого культуральну рідину центрифугували при 3000 об/хв упродовж 10 хв і фільтрували через мембранні фільтри Minisart, діаметром 0,22 мкм.

Чашки Петрі, які містили $25 \mathrm{~cm}^{3}$ МРС агару, засівали суспензією відповідних тест-культур умовнопатогенних мікроорганізмів (Escherichia coli, Salmonella enteritidis, Enterobacter aerogenes, Proteus mirabilis, Staphylococcus aureus, Pseudomonas aeruginosa) у концентрації $1 \times 10^{6} \mathrm{KУO} / \mathrm{cm}^{3}$ і витримували 1 год за температури $37{ }^{\circ} \mathrm{C}$. Після цього у середовищі спеціальним профламбованим свердлом діаметром 6 мм робили лунки і заповнювали їх отриманим супернатантом різних штамів ентерококів у кількості 100 мкл. Чашки витримували упродовж 2 год (для дифузії супернатанту), а потім інкубували в аеробних умовах упродовж 24 год за температури $37^{\circ} \mathrm{C}$.

Антагоністичну активність досліджуваних штамів ентерококів оцінювали за діаметром зон затримки росту умовно-патогенних мікроорганізмів навколо лунок. Штами ентерококів вважалися неактивними при утворенні зони затримки росту 0-5 мм, мало активними - 5-10 мм, помірно активними - 11-20 мм, більше 20 мм - високоактивними (Choi et al., 2018).

Всі дослідження проводили у трьох повтореннях. Статистичну обробку даних проводили, використовуючи пакети програм "Exsel” та "STATISTICA 7,0". Відмінності між величинами вважали достовірними при $\mathrm{P} \leq 0,05$.

\section{Результати та їх обговорення}

При визначенні здатності різних штамів ентерококів знижувати $\mathrm{pH}$ середовища на 24 годину культивування за різних температурних режимів, отримали дані, наведені у таблиці 1. Як видно з даних, на 24 год культивування за температури $25{ }^{\circ} \mathrm{C}$ два штами $E$. durans SB20 та E. durans SB18 проявили найвищу здатність знижувати $\mathrm{pH}$ середовища. Зокрема, вони знижували $\mathrm{pH}$ середовища МРС до 5,0 $\pm 0,08$ та 5,01 \pm 0,04 одиниці відповідно, що становило 24,5 та $24,4 \%$ ( $<<0,001)$ щодо контролю. Крім цього, було встановлено, що за температури $30{ }^{\circ} \mathrm{C}$, штами E. durans SB6 та SB18 здатні знижувати $\mathrm{pH}$ середовища на 26,7 та 26,4 \% відповідно. За температури культивування $37^{\circ} \mathrm{C}$ найкраще, 3 огляду зниження $\mathrm{pH}$ середовища, проявив себе штам $E$. durans SB20, оскільки був здатним знизити його на $30,3 \%$, а $E$. durans SB18 - на $29,9 \%(\mathrm{P}<0,001)$. 
Таблиця 1

Зміна рН середовища на 24 годину культивування ентерококів за різних температурних режимів

\begin{tabular}{lccc}
\hline \multicolumn{1}{c}{ Штами мікроорганізмів } & \multicolumn{3}{c}{ Температура культивування } \\
\cline { 2 - 4 } & $25{ }^{\circ} \mathrm{C}$ & $30{ }^{\circ} \mathrm{C}$ & $37^{\circ} \mathrm{C}$ \\
\hline Контроль & $6,63 \pm 0,01$ & $6,4 \pm 0,21$ & $6,64 \pm 0,03$ \\
E. durans $\mathrm{SB6}$ & $5,05 \pm 0,04 * * *$ & $4,69 \pm 0,03^{* *}$ & $4,67 \pm 0,03^{* * *}$ \\
E. faecium $\mathrm{SB} 12$ & $5,02 \pm 0,03^{* * *}$ & $4,75 \pm 0,20^{* *}$ & $4,66 \pm 0,03 * * *$ \\
E. durans $\mathrm{SB} 18$ & $5,01 \pm 0,04 * * *$ & $4,71 \pm 0,03 * *$ & $4,65 \pm 0,02^{* * *}$ \\
E. durans $\mathrm{SB} 20$ & $5,0 \pm 0,08^{* * *}$ & $4,74 \pm 0,02^{* *}$ & $4,63 \pm 0,02^{* * *}$ \\
\hline
\end{tabular}

Примітка: $* *-\mathrm{P}<0,01, * * *-\mathrm{P}<0,001$

При дослідженні здатності досліджуваних штамів ентерококів знижувати $\mathrm{pH}$ середовища на 48 годину культивування за різних температурних режимів, отримали дані, наведені у таблиці 2. Так, за результатами дослідження було встановлено, що на 48 год культивування за температури $25{ }^{\circ} \mathrm{C}$ штам $E$. durans $\mathrm{SB} 18$ та штам $E$. durans $\mathrm{SB} 20$ добре проявили себе як добрі кислотоутворювачі, оскільки знижували $\mathrm{pH}$ середовища на 27,7 та 27,6 \% відповідно. За температури $30{ }^{\circ} \mathrm{C}$ штами $E$. durans $\mathrm{SB} 18$ та $E$. durans SB20 а також штам E. faecium SB12 знижували рН на 30,0, 29,8 та 29,8 \%, відповідно. Також було встановлено, що за температури $37{ }^{\circ} \mathrm{C}$ штами E. durans SB20 та SB18 найбільше знижували $\mathrm{pH}$, на 31,1 та 30,5 \% відповідно порівняно з контролем.

Таблиця 2

Зміна рН середовища на 48 годину культивування ентерококів за різних температурних режимів

\begin{tabular}{lccc}
\hline \multicolumn{1}{c}{ Штами мікроорганізмів } & \multicolumn{3}{c}{ Температура культивування } \\
\cline { 2 - 4 } & \multicolumn{1}{c}{$25^{\circ} \mathrm{C}$} & $30^{\circ} \mathrm{C}$ & $37^{\circ} \mathrm{C}$ \\
\hline Контроль & $6,64 \pm 0,03$ & $6,6 \pm 0,02$ & $6,63 \pm 0,03$ \\
E. durans SB6 & $4,84 \pm 0,02 * * *$ & $4,64 \pm 0,03 * * *$ & $4,63 \pm 0,02^{* * *}$ \\
E. faecium SB 12 & $4,83 \pm 0,01^{* * *}$ & $4,63 \pm 0,03 * * *$ & $4,62 \pm 0,02^{* * *}$ \\
E. durans SB18 & $4,8 \pm 0,02^{* * *}$ & $4,62 \pm 0,02^{* * *}$ & $4,61 \pm 0,01 * * *$ \\
E. durans SB20 & $4,81 \pm 0,02^{* * *}$ & $4,63 \pm 0,02^{* * *}$ & $4,57 \pm 0,03 * * *$ \\
\hline
\end{tabular}

Примітка: ***- $\mathrm{P}<0,001$

Отже, отримані результати досліджень вказують на те, що штам E. durans SB20 та штам E. durans SB18 проявили найкращі кислотоуворюючі властивості, оскільки були здатними знижувати $\mathrm{pH}$ середовища при їх культивуванні як на 24 год, так і на 48 год за різних температурних режимів, зокрема $25{ }^{\circ} \mathrm{C}, 30{ }^{\circ} \mathrm{C}$ та $37{ }^{\circ} \mathrm{C}$, при цьому значення $\mathrm{pH}$ сягало 5 і менше одиниць.

У подальшому нами за зміною оптичної густини живильного середовища було визначено швидкість росту досліджуваних ентерококів. Результати дослі- джень зміни оптичної густини на 24 годину культивації наведено у табл. 3. При визначенні оптичної густини на 24 год культивування ентерококів за температури $25^{\circ} \mathrm{C}$, було встановлено, що найвищу інтенсивність росту мали штами E. durans $\mathrm{SB} 20$ та $E$. durans $\mathrm{SB} 18$, при цьому оптична густина живильного середовища була в 17,6 та 17,5 разів вищою, ніж у контролі. Також, слід зазначити, що за температури $37{ }^{\circ} \mathrm{C}$ зміна оптичної густини усіх досліджуваних штамів коливалась в межах 1,480-1,551 одиниці.

Таблиця 3

Зміна оптичної густини середовища на 24 годину культивування ентерококів за різних температурних режимів

\begin{tabular}{llcc}
\hline \multicolumn{1}{c}{ Штами мікроорганізмів } & \multicolumn{3}{c}{ Температура культивування } \\
\cline { 2 - 4 } & $25^{\circ} \mathrm{C}$ & $30^{\circ} \mathrm{C}$ & $37^{\circ} \mathrm{C}$ \\
\hline Контроль & $0,092 \pm 0,002$ & $0,091 \pm 0.026$ & $0,085 \pm 0,01$ \\
E. durans SB6 & $1,446 \pm 0,039^{* * *}$ & $1,551 \pm 0,03 * * *$ & $1,480 \pm 0,024 * * *$ \\
E. faecium SB 12 & $1,593 \pm 0,052^{* * *}$ & $1,620 \pm 0,014^{* * *}$ & $1,513 \pm 0,018^{* * *}$ \\
E. durans SB18 & $1,610 \pm 0,017^{* * *}$ & $1,632 \pm 0,023^{* * *}$ & $1,499 \pm 0,01^{* * *}$ \\
E. durans SB20 & $1,621 \pm 0,01^{* * *}$ & $1,589 \pm 0,01^{* * *}$ & $1,551 \pm 0,039^{* * *}$ \\
\hline
\end{tabular}

Примітка: $* * *-\mathrm{P}<0,001$ 
У таблиці 4 наведені результати досліджень зміни оптичної густини середовища на 48 год культивування мікроорганізмів. Зокрема, було встановлено, що за температури $25{ }^{\circ} \mathrm{C}$ найсуттєвіші зміни оптичної густини спостерігали на 48 год культивування штамів E. durans SB6 та E. faecium SB 12. Так, показники оптичної густини були відповідно в 17,7 та 17,3 рази вищими у порівнянні із значенням контрольного зразка. Проте, за температури культивування $37^{\circ} \mathrm{C}$ найвищу інтенсивність росту спостерігали при культивуванні штамів $E$. durans $\mathrm{SB} 18$ та $E$. durans SB6, де оптична густина була відповідно у 18,3 та 18,2 рази вищою у порівнянні із контрольним зразком.

\section{Таблиця 4}

Зміна оптичної густини середовища на 48 годину культивування ентерококів за різних температурних режимів

\begin{tabular}{lccc}
\hline \multicolumn{1}{c}{ Штами мікроорганізмів } & \multicolumn{3}{c}{ Температура культивування } \\
\cline { 2 - 4 } & $25^{\circ} \mathrm{C}$ & $30{ }^{\circ} \mathrm{C}$ & $37^{\circ} \mathrm{C}$ \\
\hline Контроль & $0,090 \pm 0,0037$ & $0,090 \pm 0,003$ & $0,087 \pm 0,002$ \\
E. durans SB6 & $1,594 \pm 0,02^{* * *}$ & $1,622 \pm 0,02^{* * *}$ & $1,581 \pm 0,01^{* * *}$ \\
E. faecium SB 12 & $1,561 \pm 0,027 * * *$ & $1,611 \pm 0,017^{* * *}$ & $1,563 \pm 0,02^{* * *}$ \\
E. durans SB18 & $1,539 \pm 0,018^{* * *}$ & $1,560 \pm 0,02^{* * *}$ & $1,590 \pm 0,016^{* * *}$ \\
E. durans $\mathrm{SB} 20$ & $1,552 \pm 0,035^{* * *}$ & $1,594 \pm 0,01^{* * *}$ & $1,542 \pm 0,02^{* * *}$ \\
\hline
\end{tabular}

Примітка: $* * *-\mathrm{P}<0,001$

При дослідженні антагоністичної активності супернатанту досліджуваних штамів ентерококів, які культивували упродовж 24 та 48 год за температурних режимів 25, 30, та $37^{\circ} \mathrm{C}$, щодо тест-культур E. coli, S. enteritidis, E. aerogenes, P. mirabilis, S. aureus, $P$. aeruginosa, отримали результати, наведені у таблицях 5-10. 3 наведених даних у таблиці 5, видно, що на 24 год культивування всі чотири досліджувані штами ентерококів проявили помірну антагоністичну актив- ність до тест-культури $P$. mirabilis за температури $25^{\circ} \mathrm{C}$. Проте, за цих умов антагоністична активність штамів E. durans SB6, SB18, SB20, а також штаму та $E$. faecium SB12 щодо культур як E. coli, S. enteritidis, S. aureus та $P$. aeruginosa була відсутня. Також, слід зазначити, що штами E. durans SB18 та SB20 проявляли слабку антагоністичну активність до E. aerogenes.

\section{Таблиця 5}

Антагоністична активність ентерококів упродовж 24 год культивування за температури $25^{\circ} \mathrm{C}$

\begin{tabular}{lcccc}
\hline \multirow{2}{*}{ Тест-культури } & \multicolumn{5}{c}{ Штами ентерококів } \\
\cline { 2 - 5 } & $\begin{array}{c}\text { E. durans } \\
\text { SB6 }\end{array}$ & $\begin{array}{c}\text { E. faecium } \\
\text { SB 12 }\end{array}$ & $\begin{array}{c}\text { E. durans } \\
\text { SB18 }\end{array}$ & $\begin{array}{c}\text { E. durans } \\
\text { SB20 }\end{array}$ \\
\hline E. coli & - & - & - & - \\
S. enteritidis & - & - & - & - \\
E. aerogenes & - & - & $9,6 \pm 0,3$ & $10,3 \pm 0,3$ \\
P. mirabilis & $11,6 \pm 0,3$ & $11,3 \pm 0,3$ & $10,3 \pm 0,3$ & $11,6 \pm 0,3$ \\
S. aureus & - & - & - & - \\
P. aeruginosa & - & - & - & - \\
\hline
\end{tabular}

Таблиця 6

Антагоністична активність ентерококів упродовж 48 год культивування за температури $25^{\circ} \mathrm{C}$

\begin{tabular}{lcccc}
\hline \multirow{2}{*}{ Тест-культури } & \multicolumn{4}{c}{ Штами ентерококів } \\
\cline { 2 - 5 } & $\begin{array}{c}\text { E. durans } \\
\text { SB6 }\end{array}$ & $\begin{array}{c}\text { E. faecium } \\
\text { SB 12 }\end{array}$ & $\begin{array}{c}\text { E. durans } \\
\text { SB18 }\end{array}$ & $\begin{array}{c}\text { E. durans } \\
\text { SB20 }\end{array}$ \\
\hline E. coli & $11,3 \pm 0,3$ & $11,6 \pm 0,3$ & $11,6 \pm 0,3$ & $11,6 \pm 0,3$ \\
S. enteritidis & $10,6 \pm 0,3$ & $11,3 \pm 0,3$ & $11,6 \pm 0,3$ \\
E. aerogenes & $11,3 \pm 0,3$ & $11,6 \pm 0,3$ & $10,3 \pm 0,3$ & $10,3 \pm 0,3$ \\
P. mirabilis & $12,3 \pm 0,3$ & $11,6 \pm 0,3$ & $12,3 \pm 0,3$ & $12,3 \pm 0,3$ \\
S. aureus & - & - & - & - \\
P. aeruginosa & $10,6 \pm 0,3$ & - & $11,3 \pm 0,3$ & $11,6 \pm 0,3$ \\
\hline
\end{tabular}

У таблиці 6 приведені дані антагоністичної активності досліджуваних штамів ентерококів на 48 год культивування за температури $25^{\circ} \mathrm{C}$. Слід відзначити, що на 48 год культивування у порівнянні 324 год, 
досліджувані штами були здатними пригнітити ріст більшості патогенної мікрофлори. Однак, як і на 24 год усі штами ентерококів не проявляли антагоністичну активність щодо культури $S$. aureus. Проте, було встановлено помірну антагоністичну активність усіх штамів відносно таких культур як E. coli та P. mirabilis. Штами ентерококів E. faecium SB12 та E. durans SB20 помірно пригнічували ріст $S$. enteritidis. Також, штами E. durans SB18, SB20 та SB6 проявляли помірну та слабку активність щодо $P$. aeruginosa, однак штам E. faecium SB12 не пригнічував ріст цих бактерій.

Результати антагоністичної активності ентерококів на 24 та 48 год культивування за температури $30^{\circ} \mathrm{C}$ наведено у таблицях 7 та 8. 3 даних таблиці 7 видно, що у всіх чотирьох штамів відсутня здатність пригнічувати культуру $S$. aureus. Антагоністичною активність не володіли також штами $E$. durans $\mathrm{SB} 6, E$. $d u$ rans $\mathrm{SB} 18$ та E. faecium SB12 щодо P. aeruginosa. Крім того, спостерігали помірну активність усіх штамів ентерококів до P. mirabilis та S. enteritidis. Здатність помірно пригнічувати ріст $E$. aerogenes виявлено у всіх штамів ентерококів, окрім штаму E. durans SB20, який володіс слабкою активністю. Також помірно пригнічувати ріст E. coli здатні усі штами E. durans, a штам E. faecium слабко пригнічував ріст цього мікроорганізму.

\section{Таблиця 7}

Антагоністична активність ентерококів упродовж 24 год культивуння за температури $30{ }^{\circ} \mathrm{C}$

\begin{tabular}{lcccc}
\hline \multirow{2}{*}{ Тест-культури } & \multicolumn{4}{c}{ Штами ентерококів } \\
\cline { 2 - 5 } & $\begin{array}{c}\text { E. durans } \\
\text { SB6 }\end{array}$ & $\begin{array}{c}\text { E. faecium } \\
\text { SB 12 }\end{array}$ & $\begin{array}{c}\text { E. durans } \\
\text { SB18 }\end{array}$ & $\begin{array}{c}\text { E. durans } \\
\text { SB20 }\end{array}$ \\
\hline E. coli & $11,3 \pm 0,3$ & $10,6 \pm 0,3$ & $11,3 \pm 0,3$ & $11,3 \pm 0,3$ \\
S. enteritidis & $11,3 \pm 0,3$ & $11,6 \pm 0,3$ & $12,3 \pm 0,3$ & $11,3 \pm 0,3$ \\
E. aerogenes & $12,3 \pm 0,3$ & $11,3 \pm 0,3$ & $11,3 \pm 0,3$ & $10,3 \pm 0,3$ \\
P. mirabilis & $11,3 \pm 0,3$ & $11,3 \pm 0,3$ & $11,6 \pm 0,3$ & $11,6 \pm 0,3$ \\
S. aureus & - & - & - & - \\
P. aeruginosa & - & - & - & $9,6 \pm 0,3$ \\
\hline
\end{tabular}

Також слід зазначити, що на 48 год культивування ентерококів за температури $30{ }^{\circ} \mathrm{C}$ (табл. 8), як і на 24 год досліджувані штами не пригнічували ріст $S$. aureus. Було встановлено помірну антагоністичну активність штамів E. durans SB6, SB18, SB20 та E. faecium
SB12 щодо P. mirabilis, E. aerogenes та E. coli. Помірно пригнічували ріст $P$. aeruginosa усі ентерококи штами $E$. durans крім E. faecium, який не проявляв антагонізму.

Таблиця 8

Антагоністична активність ентерококів упродовж 48 год культивування за температури $30{ }^{\circ} \mathrm{C}$

\begin{tabular}{lcccc}
\hline \multirow{2}{*}{ Тест-культури } & \multicolumn{4}{c}{ Штами ентерококів } \\
\cline { 2 - 5 } & $\begin{array}{c}\text { E. durans } \\
\text { SB6 }\end{array}$ & E. faecium & E. durans & E. durans \\
SB20
\end{tabular}

Результати антагоністичної активності ентерококів на 24 та 48 год культивування за температури $37^{\circ} \mathrm{C}$ наведено у таблицях 9 та 10. 3 даних, наведених у таблиці 9, видно, що усі досліджувані ентерококи володіли помірною антагоністичною активністю щодо P. mirabilis, E. aerogenes та S. enteritidis. Було встановлено, що штами E. durans SB6 та SB18 слабко пригнічували ріст $E$. coli, в той час як штами $E$. faeci$u m \mathrm{SB} 12$ та $E$. durans $\mathrm{SB} 20$ помірно пригнічували цей мікроорганізм. Слід відзначити значну стійкість тест- штаму $P$. aeruginosa до трьох штамів ентерококів, за винятком $E$. durans SB18, де виявили помірну антагоністичну активність.

Як видно $з$ даних, наведених у таблиці 10, усі досліджувані штами ентерококів проявляли помірну антагоністичну активність щодо E. coli, S. enteritidis, E. aerogenes, $P$. mirabilis та $P$. aeruginosa. Проте, штами E. durans SB6, SB18, SB20 та E. faecium SB 12 не проявляли антагоністичну активність до $S$. aureus. 
Таблиця 9

Антагоністична активність ентерококів упродовж 24 год культивування за температури $37^{\circ} \mathrm{C}$

\begin{tabular}{lcccc}
\hline \multirow{2}{*}{ Тест-культури } & \multicolumn{4}{c}{ Штами ентерококів } \\
\cline { 2 - 5 } & $\begin{array}{c}\text { E. durans } \\
\text { SB6 }\end{array}$ & E. faecium & E. durans \\
SB18 & $\begin{array}{c}\text { E. durans } \\
\text { SB20 }\end{array}$ \\
\hline E. coli & $10,6 \pm 0,3$ & $11,3 \pm 0,3$ & $10,6 \pm 0,3$ & $11,3 \pm 0,3$ \\
S. enteritidis & $11,6 \pm 0,3$ & $11,6 \pm 0,3$ & $11,6 \pm 0,3$ & $11,3 \pm 0,3$ \\
E. aerogenes & $11,3 \pm 0,3$ & $12,3 \pm 0,3$ & $11,6 \pm 0,3$ & $11,6 \pm 0,3$ \\
P. mirabilis & $12,3 \pm 0,3$ & $12,3 \pm 0,3$ & $12,3 \pm 0,3$ & $11,6 \pm 0,3$ \\
S. aureus & - & - & - & - \\
P. aeruginosa & - & - & $11,6 \pm 0,3$ & - \\
\hline
\end{tabular}

Таблиця 10

Антагоністична активність ентерококів упродовж 48 год культивування за температури $37{ }^{\circ} \mathrm{C}$

\begin{tabular}{lcccc}
\hline \multirow{2}{*}{ Тест-культури } & \multicolumn{4}{c}{ Штами ентерококів } \\
\cline { 2 - 5 } & $\begin{array}{c}\text { E. durans } \\
\text { SB6 }\end{array}$ & E. faecium & E. durans & SB18 \\
\hline E. coli & $12,6 \pm 0,3$ & $11,6 \pm 0,3$ & $12,3 \pm 0,3$ & $12,3 \pm 0,3$ \\
S. enteritidis & $12,6 \pm 0,3$ & $11,6 \pm 0,3$ & $12,6 \pm 0,3$ & $12,6 \pm 0,3$ \\
E. aerogenes & $12,3 \pm 0,3$ & $11,6 \pm 0,3$ & $12,3 \pm 0,3$ & $12,3 \pm 0,3$ \\
P. mirabilis & $12,3 \pm 0,3$ & $12,3 \pm 0,3$ & $12,3 \pm 0,3$ & $11,6 \pm 0,3$ \\
S. aureus & - & - & - & - \\
P. aeruginosa & $11,6 \pm 0,3$ & $11,6 \pm 0,3$ & $11,6 \pm 0,3$ & - \\
\hline
\end{tabular}

\section{Висновки}

1. Виділені з карпатської бринзи штами ентерококів E.durans SB6, E.durans SB18, E.durans SB20 E. faecium SB12 проявляли високу здатність знижувати кислотність середовища на 24 та 48 год культивування за температурних режимів 25,30 та $37^{\circ} \mathrm{C}$. Було встановлено, що найвищу здатність знижувати кислотність середовища за температури $37^{\circ} \mathrm{C}$ проявили штами E.durans SB 20 та E.durans SB 18, зокрема, на 24 культивування рН середовища знижувалося на 30,3 та 29,9\%, а на 48 год - на 31,1 та 30,6 \% відповідно.

2. Досліджувані штами ентерококів проявляли різну антагоністичну активність щодо грам-негативних представників умовно-патогенної мікрофлори, зокрема E. coli, $S$. enteritidis, $E$. aerogenes, $P$. mirabilis, $P$. aeruginosa, проте до грам-позитивних мікроорганізмів - S. aureus антагоністичної дії не встановили. Було встановлено, що із збільшенням температури культивування ентерококів зростала їх антагоністична активність. Зокрема, найоптимальнішою температурою культивування була $37^{\circ} \mathrm{C}$. За таких умов тільки штам E.durans SB18 проявив помірну антагоністичну активність до усіх досліджуваних грам негативних мікроорганізмів, у тому числі $P$. aeruginosa.

3. 3 проведених досліджень можна зробити висновок, що виділені з карпатської бринзи штами ентерококів E.durans та E. faecium можуть бути предметом для подальшого вивчення 3 метою залучення їх у склад нового вітчизняного бактеріального препарату.

\section{References}

Botyna, S. G. (2008). Vydovaja ydentyfykacyja y genetycheskaja pasportyzacyja molochnokyslyyh bakteryj metodamy molekuljarno-genetncheskogo typyrovanyja. Molochnaja promyyshlennost', 3, 50-52 (in Ukrainian).

Braïek, O. B. \& Smaoui, S. (2019). Enterococci: Between Emerging Pathogens and Potential Probiotics. Hindawi BioMed Research International, 2019, Article ID 5938210. doi: 10.1155/2019/5938210.

Choi, A. R., Patra, J. K., Kim, W. J., \& Kang, S. S. (2018). Antagonistic Activities and Probiotic Potential of Lactic Acid Bacteria Derived From a Plant-Based Fermented Food. Front Microbiol, 9, 1-12. doi: 10.3389/fmicb.2018.01963.

Dehtjarenko, H. V., Shynkarenko, L. M., \& Dugan, O. M. (2007). Kryterii' vidboru probiotychnyh shtamiv mikroorganizmiv. Naukovi Zapysky. Biologija ta ekologija, 67, 30-36 (in Ukrainian).

Duc, Le. H., Hong, H. A., Barbosa, M. T. et al. (2004). Characterization of Bacillus Probiotics Avialable fro Human use. Applied and Environmental Microbiology, 70(4), 2161-2171. doi: 10.1128/AEM.70.4.21612171.2004.

Ezendam, J., Opperhuizen A., \& van Loveren, H.(2005). Immunomodulation by probiotics: efficacy and safety evaluation. RIVM report 340320003.

Franz, C., Schillinger, U., \& Holzapfel, W. H. (1996). Production and characterization of enterocin 900, a bacteriocin produced by Enterococcus faecium BFE 900 from black olives. International Journal of Food 
Microbiology, 29(2-3), 255-270. doi: 10.1016/01681605(95)00036-4.

Giraffa, G. (2003). Functionality of enterococci in dairy products. International Journal of Food Microbiology, 88(2-3), 215-222. doi: 10.1016/S0168-1605(03)00183-1.

Gordijenko, P. A., Chujeshov, V. I., \& Pashnjeva, R. O. (2009). Rozrobka skladu ta tehnologii' tabletok-jader kombinovanogo probiotyka. Farmakom, 3, 19-23 (in Ukrainian).

Hyzhnjak, O. S. (2017). Rozrobka skladu ta biotehnologii' otrymannja kompleksnogo probiotychnogo preparatu: avtoref. dys. na zdobuttja nauk. stupenja kandydata farmac. nauk: spec. 15.00.01 "Tehnologija likiv, organizacija farmacevtychnoi' spravy ta sudova farmacija". Harkiv (in Ukrainian).

Jankovskij, D. S., Shirobokov, V. P., Moiseenko, R. A. et al. (2010). Disbiozy i sovremennye podhody $\mathrm{k}$ ih profilaktike. Sovremennaja pediatrija, 3(31), 143-151 (in Ukrainian).

Jankovskyj, D. S., Moyseenko R. A., \& Dyyment, G. S. (2009). Osobennosty otechestvennyyh mul'typrobyotykov. Sovremennaja pedyatryja, 3(25), 79 86 (in Ukrainian).

Jushhuk, N. D. \& Brodov L. E. (2001). Ostrye kishechnye infekcii: diagnostika i lechenie. Medicina, 244-253 (in Russian).

Sarantinopoulos, P., Andrighetto, C., Georgalaki M.D. et al. (2001). Biochemical properties of enterococci relevant to their technological performance. International Dairy Journal, 11(8), 621-647. doi: 10.1016/S0958-6946(01)00087-5.

Shenderov, B. A. (2001). Medicinskaja mikrobnaja jekologija i funkcional'noe pitanie. T. 3. Probiotiki i funkcional'noe pitanie. GRANT (in Russian).
Shyrobokov, V. P., Jankovs'kyj, D. S., \& Dyment, G. S. (2008). Mikrobna ekologija ljudyny z kol'orovym atlasom: [navch. posib.]. TOV "Chervona Ruta-Turs" (in Ukrainian).

Slyvka, I. M., Tsisaryk, O. Y., Dronyk, G. V., \& Musiy L. Y. (2018). Strains of lactic acid bacteria isolated from traditional Carpathian cheese. Regul. Mech. Biosyst., 9(1), 62-68. doi: 10.15421/021808.

Sornplang, P. \& Piyadeatsoontorn, S. (2016). Probiotic isolates from unconventional sources: a review. Journal of Animal Science and Technology, 58, 26. doi: 10.1186/ s40781-016-0108-2.

Strel'nikov, L. S., Strilec, O. P., Shherbak, O. V. et al. (2006). Perspektivy i puti razvitija proizvodstva biotehnologicheskih lekarstvennyh preparatov $\mathrm{v}$ Ukraine. Annals of Mechnicov Institute, 4, 3-8 (in Ukrainian).

Tihomirova, N. A. (2002). Tehnologija produktov funkcional'nogo pitanija: monogr. Frantjera, 213 p (in Russian).

Tuomola, E., Crittenden, R., Playne, M. et al. (2001). Quality assurance criteria for probiotic bacteria. American Journal of Clinical Nutrition, 73, 393-398. doi: 10.1093/ajen/73.2.393s.

White, H. (2008). The effect of variation in $\mathrm{pH}$ on the heat resistance of cultures of Streptococcus faecalis. Journal of applied bacteriology, 26(1), 91-99. doi: 10.1111/j.1365-2672.1963.tb01161.x.

Yaneisy, G. H., Tania, P. S., Ramón, B., José, L., Balcázar, J. R., Nicoli, J. M. S., et al. (2016). Isolation, characterization and evaluation of probiotic lactic acid bacteria for potential use in animal production. Res Vet Sci, 108, 125-32. doi: 10.1016/j.rvsc.2016.08.009. 